\title{
Phytoplankton distribution and their relationship to environmental variables in Sanya Bay, South China Sea
}

\author{
YANYING ZHANG ${ }^{1,2}$, JUNDE DONG $^{1,2}$, JUAN LING $^{1,2}$, YOUSHAO WANG $^{1}$ \\ and SI ZHANG ${ }^{1}$ \\ ${ }^{1}$ Key Laboratory of Marine Bio-resources Sustainable Utilization, South China Sea Institute of Oceanology, \\ Chinese Academy of Sciences, Guangzhou 510301, P.R. China. E-mail: amy0517@ gmail.com \\ ${ }^{2}$ Hainan Tropical Marine Biology Station, CAS, Sanya 572000, P.R. China.
}

\begin{abstract}
SUMMARY: Phytoplankton quantification was conducted in Sanya Bay from January 2005 to February 2006. A submersible in situ spectrofluorometer, which permits the differentiation of four algal groups (green algae, diatoms and dinoflagellates, cryptophytes and cyanobacteria) was used. Seasonal variation of total chlorophyll $a$ concentration showed that high value appeared in summer and low concentration occurred in spring. Diatoms and dinoflagellates group was the predominant phytoplankton all year in the Bay. The stable stratification of phytoplankton vertical distribution came into being in July. During the stratification event, the total chlorophyll $a$ concentration of deep layer was much higher than the surface; cyanobacteria and cryptophyta groups decreased and almost disappeared, however, the concentration of green algae and diatoms and dinoflagellates groups increased. In deep layer, the concentration of diatoms and dinoflagellates group increased sharply, which was about eight times more than that in the surface layer. The vertical profiles character of phytoplankton showed that from inshore stations to outer bay the stratification of phytoplankton vertical distribution gradually strengthened. Dissolved inorganic nutrient especially phosphate and inorganic nitrogen and cold-water upwelling were the main regulating factor for phytoplankton distribution.
\end{abstract}

Keywords: phytoplankton, chlorophyll $a$, environmental variables, thermocline, Sanya Bay.

RESUMEN: DistribUCión DEL FITOPLANCTON Y SU RELACIÓN CON VARIABLES AMBIENTALES EN SANYA BAY, MAR DEL SUR DE LA CHINA. - Desde enero 2005 a febrero 2006, en Sanya Bay se llevó a cabo la cuantificación del fitoplancton. Para ello se usó un espectrofotómetro sumergible in situ que permitía la diferenciación de cuatro grupos de algas (algas verdes, diatomeas y dinoflagelados, criptofitas y cianobacterias). La variación estacional de la concentración de clorofila $a$, mostraba que los valores altos aparecían en verano y los bajos en invierno. Durante todo el año el grupo de fitoplancton predominante era el de dinoflagelados y diatomeas. La estratificación estable de la distribución vertical del fitoplancton aparecía en julio. Durante la estratificación la concentración total de la clorofila $a$ de la capa profunda era más alta que en la superficie; los grupos de crisófitas y cianobacterias decrecían hasta casi desaparecer, sin embargo la concentración de algas verdes y diatomeas se incrementaba. En la capa profunda la concentración del grupo formado por diatomeas y dinoflagelados se incrementaba considerablemente con concentraciones ocho veces más elevadas que en la superficie. El carácter de los perfiles verticales de fitoplancton desde las estaciones costeras hasta fuera de la Bahía aparecía gradualmente más definido. Los nutrientes inorgánicos correspondientes a fósforo y nitrógeno junto con la subida de agua fría eran los factores principales que regulaban la distribución del fitoplancton.

Palabras clave: fitoplancton, clorofila $a$, variables ambientales, termoclina, Sanya Bay.

\section{INTRODUCTION}

Phytoplankton, as the primary producer in food webs, is the basic biological resources of marine ecosystem. Changes in phytoplankton populations and community structure have a direct impact on the marine ecosystem structure and function. The precise knowledge of the phytoplankton spatial distribution patterns constitutes a powerful tool for an oceanologically-based dynamic coastal management and must 

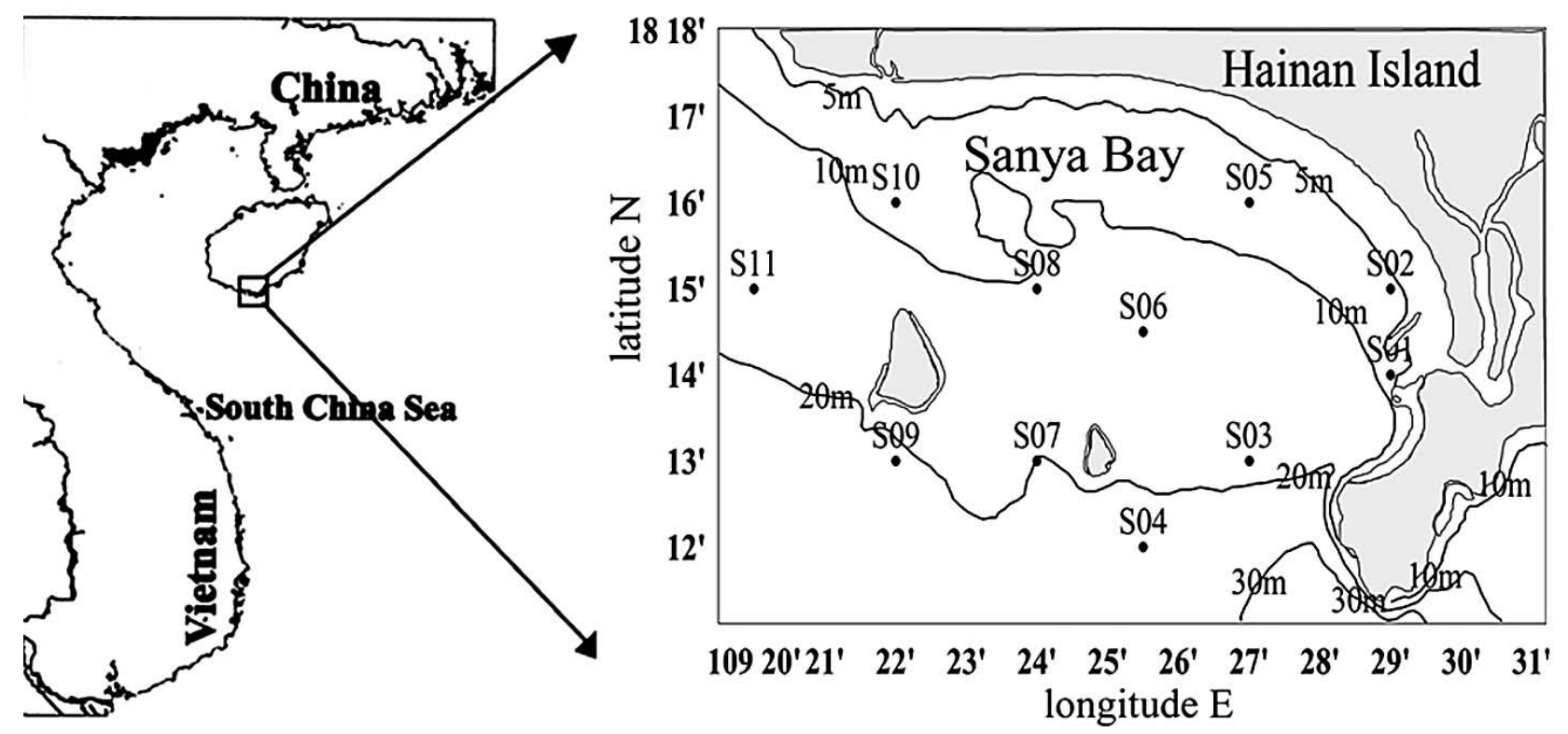

FIG. 1. - Location of 11 sampling stations in Sanya Bay (Dong et al., 2008).

be integrated in marine water quality monitoring procedures. The use of fast-response and high-resolution technologies, such as a submersible fluorometer, should significantly help in reaching this objective. The algae of the same division contain a similar quantity and quality of photosynthetic pigments, and their fluorescence excitation spectrum (with a fixed emission wavelength at $680 \mathrm{~nm}$ ) is significant for each division. So it is possible to differentiate divisions of algae by their fluorescence excitation spectrum. A submersible fluorometer with several excitation and emission wavelength bands was introduced by Desiderio et al. (1997). Beutler et al. (2002) presented a device (FluoroProbe, bbe-Moldaenke, Kiel, Germany) that was able to discriminate four spectral classes of phytoplankton (default 'green' - green algae, 'blue' - phycocyanin containing cyanobacteria, "brown" diatoms, dinoflagellates, and 'mixed' - cryptophyta) according to their fluorescence excitation spectra and also determined their quantity in units $\mu \mathrm{g}$ chlorophyll $a$ per $\mathrm{ml}$. The validation studies for the determination of the total chlorophyll $a$ and composition of phytoplankton communities compared to the standard laboratory methods for phytoplankton quantification, concentration of chlorophyll $a$ and microscopy analysis were carried out. A high correlation between chlorophyll $a$ levels using different methods was found in all types of phytoplankton community. Taxonomic analyses and cell counts were closely related to the ratio of algal classes measured by the in situ spectrofluorometer (Gregor and Marsalek, 2004; Gregor et al., 2005; Gregor et a.,l 2007). Recently, the submersible fluorometer was used widely for the in situ monitoring of phytoplankton communities in marine and freshwater environments and have been accepted as a quick, simple, and useful tool for quantification of phytoplankton organisms (Serra et al., 2007; Arn- aud et al., 2008; Blanco et al.,2008; Znachor1 et al., 2008; Ziegmann et al., 2010; Izydorczyk et al., 2009).

Sanya Bay is a typical tropical bay of Hainan Island in China. It encompasses a high diversity of natural habitats, ranging from coral reefs, rocky and sandy shores and mudflats to mangroves. Coral reefs are key ecosystems that are important for maintaining the regional marine resources and biodiversity (Wilkinson, 2000; Zhang, 2001; Huang et al., 2003). The previous traditional biological and ecological studies in the Bay were mainly focused on the survey of phytoplankton species and abundance (Wang et al., 2002; Huang et al., 2003). The results showed that there was higher phytoplankton abundance in the coast near the city and its adjacent water, while the mouth of the bay always showed a lower value than that in the inner bay (Huang et al., 2003). The distribution feature mainly resulted from the terrestrial input from the Sanya River and invasion by the offshore oceanic sea water. Phytoplankton abundance peaked in autumn and was lowest in spring (Huang et al., 2003) and diversity was very high (Huang et al., 2003; Zhou et al., 2007; Yang et al., 2007). Sanya Bay is affected by an allochthonous cold-water upwelling (Dong et al., 2002; Huang et al., 2003). The stronger northeast monsoon prevails from November to March, causing vertical mixing of water column, and the Southwest monsoon from May to September predominates, causing stable and stratified water column. However, vertical variations of phytoplankton concentration and community structure succession during thermocline events are poorly known. In this study, a submersible fluorometer (FluoroProbe, bbe-Moldaenke, Kiel, Germany) was applied to quantification of the seasonal and vertical variation of phytoplankton in Sanya Bay. The aim of this study was to determine the vertical and spatial distribution and seasonal variation of phytoplankton and its response to environmental variables in Sanya Bay. 


\section{MATERIALS AND METHODS}

Sanya Bay lies in the southernmost part $\left(109^{\circ} 20^{\prime}\right.$ $109^{\circ} 30^{\prime} \mathrm{E}, 18^{\circ} 11^{\prime}-18^{\circ} 18^{\prime} \mathrm{N}$ ) of Hainan Island in China (Fig. 1), with an area of $120 \mathrm{~km}^{2}$ and an average depth of $16 \mathrm{~m}$. The mean relative humidity is about $79 \%$. The annual average air temperature and rainfall are $25.5^{\circ} \mathrm{C}$ and $1279 \mathrm{~mm}$, respectively. The rainy season is from May to October, and dry season from November to April. The Sanya River, is located in the eastern part of the bay (length $31 \mathrm{~km}$, drainage area $337 \mathrm{~km}^{2}$ and has an annual flow of $2.11 \times 10^{9} \mathrm{~m}^{3}$ ).

Sampling stations were located at water depths $<20$ m, except Station $4(26 \mathrm{~m})$ and Station $9(28 \mathrm{~m})$. The survey stations were designed as follows:

1) Fix station S03: the sample was collected monthly from April to September, when the Southwest monsoon predominates.

2) The vertical and spatial distribution of phytoplankton was surveyed along two transects in July. Transect 1 was from the innermost part to outer bay and the researched stations include station S01, S03, and S04. Transect 2 was oriented in a SE-NW direction and include station S03, S06, S08, and S10 (Fig. 1).

3) All stations in the Bay, including from S01 to S11, were surveyed seasonally to evaluate the potential environmental variables influence on phytoplankton distribution.

Four seasonal sampling in the Bay were conducted in winter (January 12-13), spring (April 19-20), summer (July 10-11), and autumn (November 5-6) in 2005, respectively. Water samples were taken at the surface and from the bottom layers of all stations in both the dry season (January and April) and the wet season (July and November) in 2005. Two transects sampling were the same as seasonal sampling conducted in July 10-11. Monthly sampling of in situ water temperature and phytoplankton at fixed station $\mathrm{S} 03$ were conducted in April 20, May16, June 25, July 11, August 21 and September 21 to evaluate the Southwest monsoon influence on temporal and vertical phytoplankton distribution and water temperature.

A Quanta Water Quality Monitoring System (Hydrolab Corporation, USA) was employed to collect the data for salinity in the surface and bottom layers. Water samples for the analysis of dissolved organic nutrients were collected according to the methods and sampling tools of "Specification for Oceanography
Survey" (GB12763-91, China). After collection, the water samples were filtered immediately through precleaned $0.45 \mu \mathrm{m}$ pore-size cellulose filters for laboratory analyses of nutrients. The samples were preserved deep frozen in the dark before analysis. Sample analyses were carried out at the National Experiment Station of Tropical Marine Biology, Sanya, Hainan Island, China and at the South China Sea Institute of Oceanology, Chinese Academy of Sciences. The units and analytical methods for the various physico-chemical parameters are summarized in Table 1 (Huang et al., 2003; GB12763-91, China). The samples included those taken at the surface and the bottom, and the data for this paper are given as mean values between the surface and bottom.

Fluorescence profiles of different phytoplankton communities were carried out using a submersible spectrofluorometer FluoroProbe (bbe-Moldaenke, Kiel, Germany). This probe determines four different communities (green algae, cyanobacteria, diatoms and dinoflagellates, and cryptophytes), which have been previously calibrated by the manufacturer by considering particular algae populations corresponding to each algae group. It measures chlorophyll $a$ fluorescence $(685 \mathrm{~nm})$ excited by six different wavelengths $(370$, $470,525,570,590$, and $610 \mathrm{~nm}$ ) and calculates the amount of four phytoplankton groups in $\mu \mathrm{g}$ chlorophyll $a$ per $\mathrm{ml}$, as well as the total chlorophyll $a$ concentration. Water depth, temperature and fluorescence data were stored in the probe and transferred to a PC in the laboratory. Sample water speed across the measuring probe during depth profiling was about $30 \mathrm{~cm} \mathrm{~s}^{-1}$. For a more detailed description of the fluoroprobe, see Beutler et al. (2002) and Gregor et al. (2005).

Data analysis was performed using SPSS 13.0. Pearson correlation analysis was applied and probabilities $(P)$ of $<0.05$ were considered to be significant. Surfer 8.0 and Sigmplot 2001 are applied to make the figures.

\section{RESULTS}

\section{Vertical and spatial distribution of temperature and phytoplankton}

At permanent station S03 the highest temperature occurred in September and the lowest in January (Fig. 2 ). The deep layer water temperature declined from

TABLE 1. - Environmental parameters determined and analytical methods used in this study (Huang et al., 2003; GB12763-91, China).

\begin{tabular}{|c|c|c|c|c|}
\hline Variables & Abbreviation & method & Instrument used & Units \\
\hline Temperature & $\mathrm{T}$ & Measure in situ & FluoroProbe & ${ }^{\circ} \mathrm{C}$ \\
\hline Salinity & $\mathrm{S}$ & Measure in situ & $\begin{array}{c}\text { A Quanta Water Quality Monitoring System } \\
\text { (Hydrolab Corporation, USA) }\end{array}$ & \\
\hline Nitrate & $\mathrm{NO}_{3}-\mathrm{N}$ & $\begin{array}{l}\text { Diazotizing sulfanilamide } \\
\text { Zinc - Cadmium Reduction }\end{array}$ & Spectrophotomerter & $\mu \mathrm{mol} \mathrm{L}-1$ \\
\hline Nitrite & $\mathrm{NO}_{2}-\mathrm{N}$ & Diazo - azo method & Spectrophotomerter & umol L-1 \\
\hline Phosphate & $\mathrm{PO}_{4}-\mathrm{P}$ & Coloured molybdophosphoric blue & Spectrophotomerter & $\mu \mathrm{mol} \mathrm{L}-1$ \\
\hline Silicate & $\mathrm{SiO}_{3}-\mathrm{Si}$ & Silicon-molybdenum blue & Spectrophotomerter & $\mu \mathrm{mol} \mathrm{L}-1$ \\
\hline Ammonia & $\mathrm{NH}_{4}^{3}-\mathrm{N}$ & Oxidized by hyprobromite & Spectrophotomerter & $\mu \mathrm{mol} \mathrm{L}-1$ \\
\hline
\end{tabular}




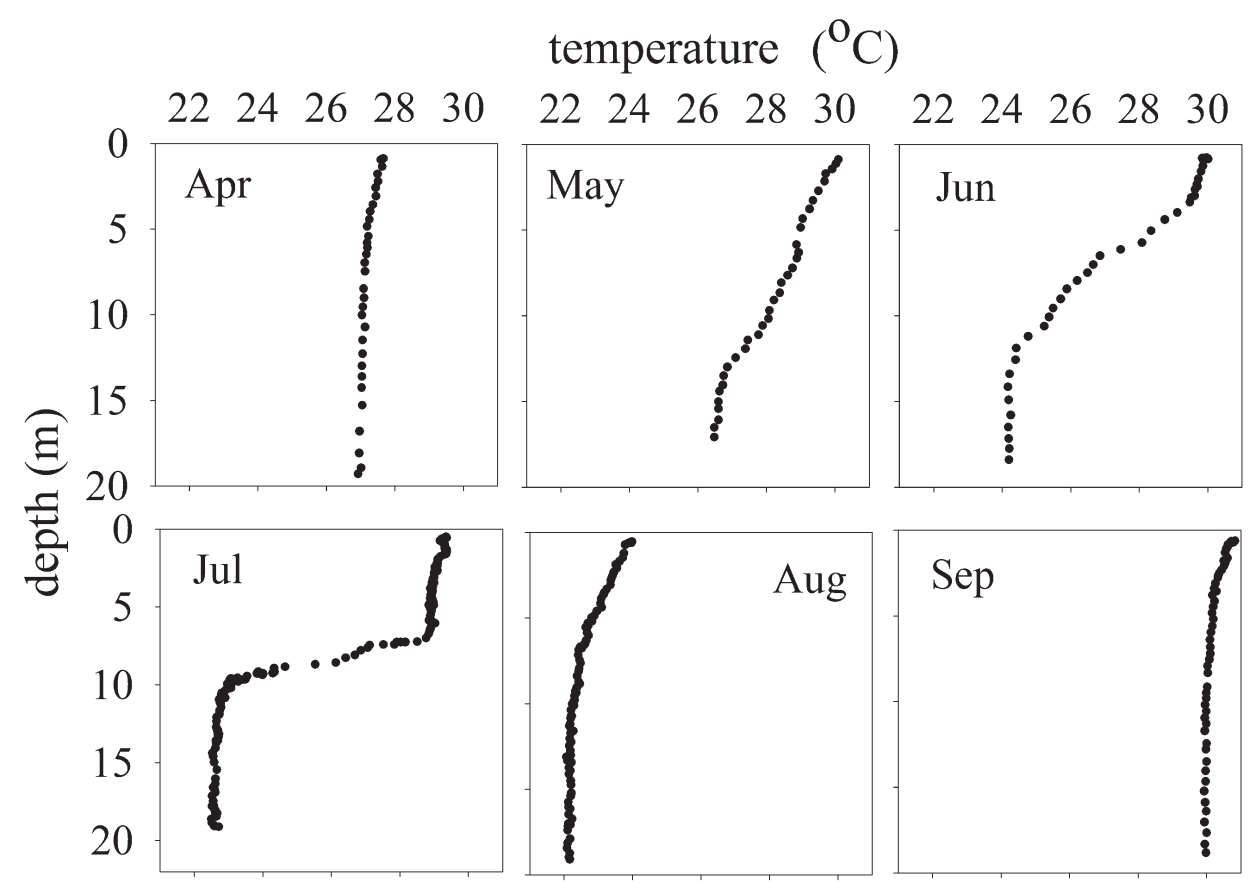

FIG. 2. - Vertical variations of temperature at fixed station S03 from April to September.

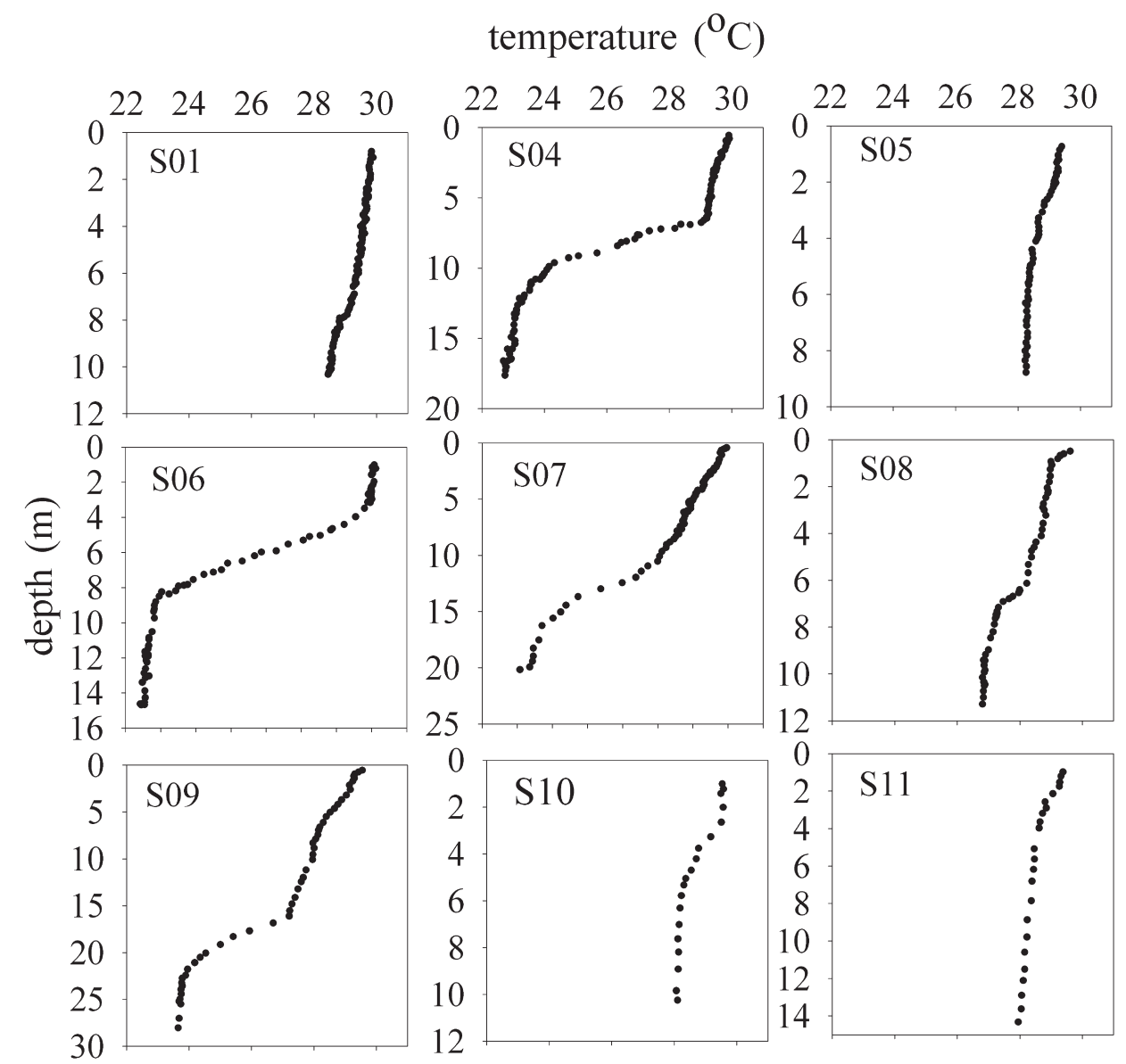

FIG. 3. - Vertical profiles of temperature at station S01, S04, S05, S06, S07, S08, S09, S10 and S11 in July. 
TABLE 2. - Seasonal variation of phytoplankton composition (\%) in Sanya Bay.

\begin{tabular}{lcccr}
\hline groups & Spring & Summer & Autumn & Winter \\
\hline diatoms & 81.35 & 83.01 & 77.47 & 79.29 \\
$\begin{array}{l}\text { and dinoflagellates } \\
\text { green algae }\end{array}$ & 16.60 & 16.58 & 2.37 & 15.37 \\
cyanobacteria & 1.11 & 0.16 & 16.78 & 3.95 \\
cryptophyta & 0.94 & 0.25 & 3.38 & 1.39 \\
\hline
\end{tabular}

June. In July, the water was stable and stratified. The thermocline was situated at a depth of $6-13 \mathrm{~m}$ and was at its strongest in July. From August, the water temperature began to mix and the surface water temperature dropped sharply to $24^{\circ} \mathrm{C}$. The deep layer water temperature declined to $22^{\circ} \mathrm{C}$ in August, which was the lowest in the year. In September the temperature increased rapidly. Both the surface and deep layer water temperature increased to $30^{\circ} \mathrm{C}$ and was the highest in the year (Fig. 2).

During the investigation of transect 1 there was no obvious thermocline found at station S01, which located at the estuary of Sanya River. Remarkable thermocline was detected at station S03 and S04 (Fig. 2, Fig. 3). The maximum thermocline intensity averaged $1.19^{\circ} \mathrm{C} \mathrm{m}^{-1}$ was detected at station $\mathrm{S} 03$, and situated at the depth of 6-13 m (Fig. 2). The maximum thermocline intensity of station S04 situated at a depth of 6.5$12 \mathrm{~m}$, with an averaging intensity of $1.053^{\circ} \mathrm{C} \mathrm{m}^{-1}$. At station S04 the temperature of deep layer was $7.23^{\circ} \mathrm{C}$ lower than the surface layer (Fig. 3). On the S03-S10 transect, remarkable thermocline was detected at both station S03 and S06. However, clear thermocline was not observed at station S08 and S10 (Fig. 3).

The annual mean chlorophyll $a$ was $1.62 \mathrm{mg} \mathrm{m}^{-3}$ in Sanya Bay. More than $75 \%$ of total phytoplankton chlorophyll $a$ was consisted of diatoms and dinoflagellates (Table 2). More than $15 \%$ of the phytoplankton chlorophyll $a$ was green algae during winter, spring and summer, but the number sharply decreased in autumn. The concentration of cyanobacteria increased greatly and accounted for more than $15 \%$ of phytoplankton chlorophyll $a$ in autumn.

Figure 4 shows that total chlorophyll $a$ concentration of station S03 increased rapidly during the stratification event. The lowest total chlorophyll $a$ concentration of surface layer was detected in April $(0.24 \mathrm{mg}$ $\mathrm{m}^{-3}$ ), and increased from June (Fig. 4). The highest value of surface layer chlorophyll $a$ concentration was detected in September $\left(1.91 \mathrm{mg} \mathrm{m}^{-3}\right)$. The stratification appeared from June and was in its strongest in July. During the stratification event the chlorophyll $a$ concentration of deep layer was much higher than that of the surface. In July the chlorophyll $a$ concentration of deep layer ranged from 4.0-6.77 $\mathrm{mg} \mathrm{m}^{-3}$ (averaged $5.83 \mathrm{mg} \mathrm{m}^{-3}$ ), while the chlorophyll $a$ concentration of surface layer was about $1.0 \mathrm{mg} \mathrm{m}^{-3}$. The chlorophyll $a$ concentration of deep layer decreased from August. In September the total chlorophyll $a$ concentration of deep layer was lower than the surface layer. The chlorophyll $a$ concentration of deep layer was low and distributed evenly in November. Remarkable shift was found in phytoplankton composition. Diatoms and dinoflagellates was the predominant population all the year

\section{chl a concentration $\left(\mathrm{mg} \mathrm{m}^{-3}\right)$}

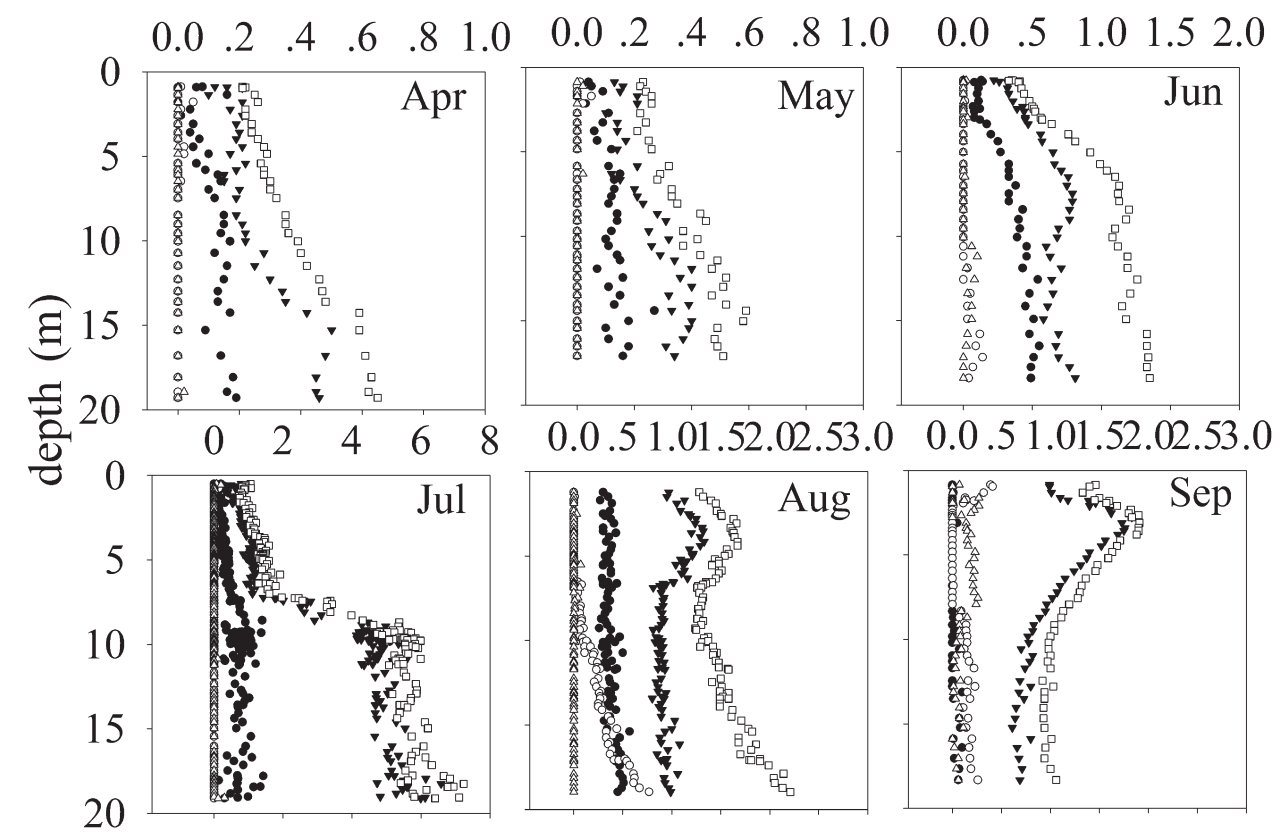

FIG. 4. - Vertical profiles of green algae (circles), cyanobacteria (empty-circles), diatoms and dinoflagellates (down-triangles), cryptophyta (up-triangles), and total chlorophyll $a$ concentration(squares) at fixed station S03 from April to September in Sanya Bay. 


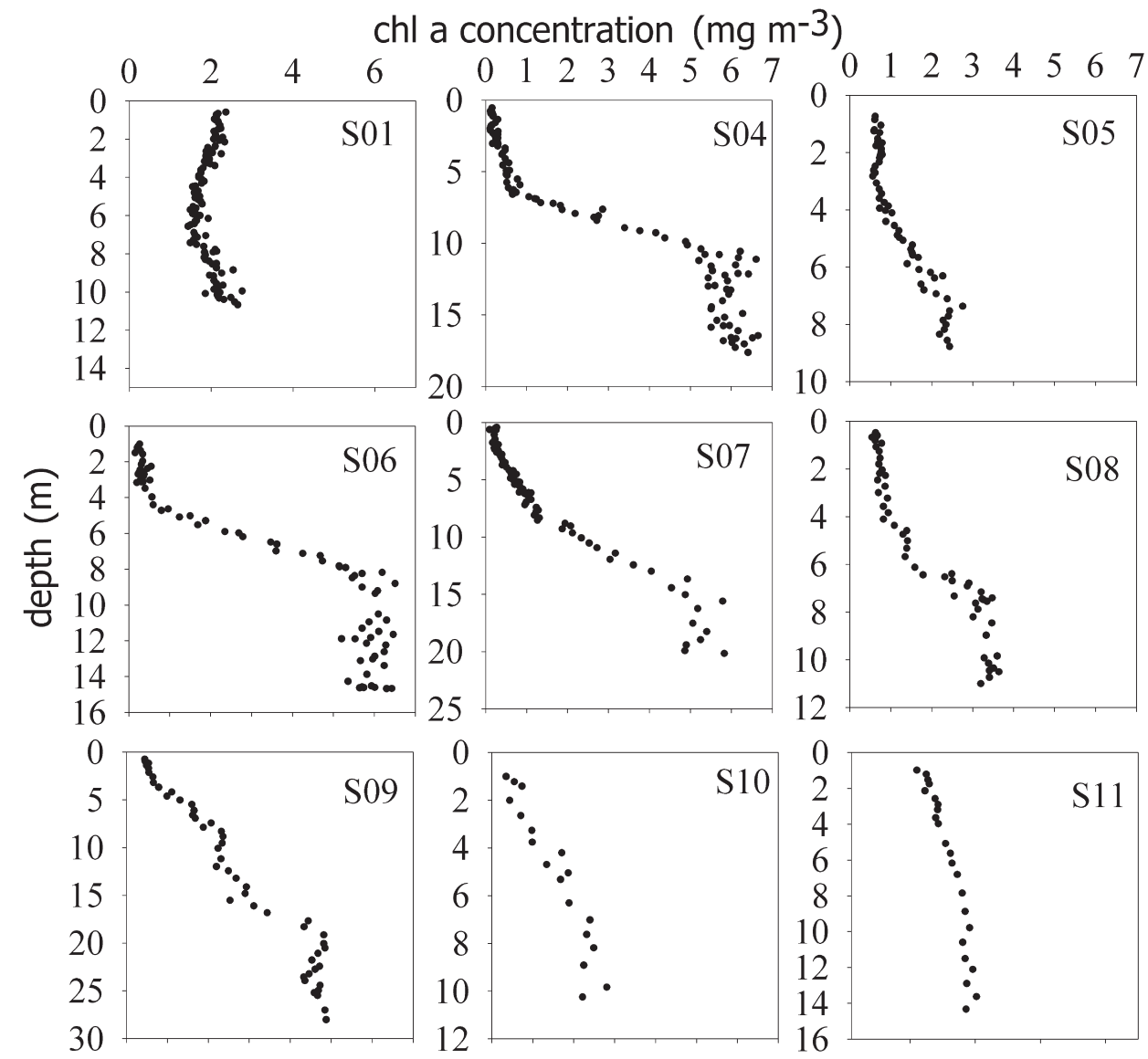

FIG. 5. - Vertical variation of phytoplankton chlorophyll $a$ concentration at station S01, S04, S05, S06, S07, S08, S09, S10 and S11 in July.

round. In September, the concentration of green algae decreased, while the concentration of cyanobacteria and cryptophyceae increased greatly. Green algae were in highest concentration in December, and the highest concentration was $0.6 \mathrm{mg} \mathrm{m}^{-3}$ at station S03 (Fig. 4).

The vertical profiles of phytoplankton showed that remarkable differences in vertical distribution detected at outer bay stations S03, S04, and S06. Slight stratification was found at station S08 and S10, while no stratification observed at station S01 (Fig. 5). Our results of spatial distribution of temperature and phytoplankton showed that from inshore stations to outer bay the thermocline and stratification of phytoplankton vertical distribution gradually strengthened. The area of maximum thermocline and stratification of phytoplankton vertical distribution was situated at the southwest direction of the Bay, where the water depth was about $20 \mathrm{~m}$. The thermocline and stratification situated at a depth of 3-12 $\mathrm{m}$ and varied according to the water depth (Fig. 5).

\section{The relationships between environmental variables and algal groups}

The environmental variables at 11 stations in Sanya Bay in 2005 are summarized in Table 3. The average of temperature was highest in autumn and lowest in winter.
The average salinity varied from 31.59 to 34.33 . Table 4 showed that temperature was the main limiting factor on phytoplankton in winter and summer. In winter and summer, temperature was significantly negatively correlated with green algae, diatoms and dinoflagellates, and total chlorophyll $a$ concentration. In winter and autumn temperature showed significantly positive correlation with cyanobacteria and cryptophyta.

Seasonal variations of average salinity showed that in 2005 the highest average salinity occurred in winter and the lowest in autumn. Correlation analysis showed that salinity was the limiting factor on phytoplankton in spring and summer. It showed significant positive correlation with total chlorophyll $a$ concentration and diatoms and dinoflagellates group in summer, and negative correlation with green algae, diatoms and dinoflagellates, and total chlorophyll $a$ concentration in spring (Tables 3 and 4).

$\mathrm{NO}_{3}-\mathrm{N}$ was the dominant dissolved inorganic nitrogen form, accounting for more than $60 \%$ of dissolved inorganic nitrogen, followed by $\mathrm{NH}_{4}-\mathrm{N}$. Average concentration of dissolved inorganic nitrogen (including nitrate, nitrite, and ammonia) ranged from 1.18 to 7.93 $\mu \mathrm{mol} \mathrm{L} \mathrm{L}^{-1}$ among 11 investigated stations. The highest mean value of dissolved inorganic nitrogen was detected at S1, which located at the estuary of Sanya Rive. 
TABLE 3. - Ranges and means of environmental variables at different stations and seasons in Sanya Bay during the study period.

\begin{tabular}{|c|c|c|c|c|c|c|c|c|c|c|c|}
\hline stations & $\begin{array}{c}\text { range } \\
\text { mean } \pm \text { std. }\end{array}$ & $\begin{array}{c}\text { Temperature } \\
\left({ }^{\circ} \mathrm{C}\right)\end{array}$ & Salinity & $\begin{array}{c}\mathrm{NO}_{3}-\mathrm{N} \\
\left(\mu \mathrm{mol} \mathrm{L}^{-1}\right)\end{array}$ & $\begin{array}{c}\mathrm{NO}_{2}-\mathrm{N} \\
\left(\mu \mathrm{mol} \mathrm{L}^{-1}\right)\end{array}$ & $\begin{array}{c}\mathrm{NH}_{4}-\mathrm{N} \\
\left(\mu \mathrm{mol} \mathrm{L} \mathrm{L}^{-1}\right)\end{array}$ & $\begin{array}{c}\mathrm{PO}_{4}-\mathrm{P} \\
\left(\mu \mathrm{mol} \mathrm{L}^{-1}\right)\end{array}$ & $\begin{array}{c}\mathrm{SiO}_{3}-\mathrm{Si} \\
\left(\mu \mathrm{mol} \mathrm{L}^{-1}\right)\end{array}$ & $\mathrm{Si} / \mathrm{N}$ & $\mathrm{Si} / \mathrm{P}$ & $\mathrm{N} / \mathrm{P}$ \\
\hline \multirow[t]{2}{*}{ S01 } & n-Max & 68 & $.6-34.66$ & $1.00-24.05$ & .38 & $0.10-12.99$ & .09-1.49 & $11.75-99$ & $1.37-($ & $31.21-2$ & $8.44-106.22$ \\
\hline & & & & & & & & & & & \\
\hline \multirow[t]{2}{*}{$\mathrm{S} 02$} & Min-Max & $21.86-29.39$ & & & & & & & & & \\
\hline & Mean \pm Std. & & & & $18 \pm 0.33$ & & $0.11 \pm 0.10$ & & & & \\
\hline \multirow[t]{2}{*}{$\mathrm{S} 03$} & Min-Max & $22.71-27.82$ & $3.63-34.77$ & & & & & & & & $6.79-69.54$ \\
\hline & & $25.74 \pm 2.35$ & & & & & & & & $231.22 \pm 168.51$ & $39.73 \pm 22.71$ \\
\hline \multirow[t]{2}{*}{ S04 } & & & & & & & & & & & \\
\hline & Mean \pm Std. & & & & & & & & & & \\
\hline \multirow[t]{2}{*}{ S05 } & & & & & & & & & & & \\
\hline & Mean \pm Std. & 26.6 & & & & & & & & & \\
\hline \multirow[t]{2}{*}{ S06 } & Min-Max & & & & & & & & & & \\
\hline & & & & & & & & & & & \\
\hline \multirow[t]{2}{*}{ S07 } & Min- 1 & & & & & & & & & & \\
\hline & & & & & & & & & & & 497 \\
\hline \multirow[t]{2}{*}{ S08 } & Min-1 & 23.3 & & & & & & & & & 0.27 \\
\hline & Mean & & & & & & & & & & \\
\hline \multirow[t]{2}{*}{ S09 } & & & & & & & & & & & \\
\hline & & & & & & & & & & & \\
\hline \multirow[t]{2}{*}{$\mathrm{S} 10$} & & & & & & & & & & & \\
\hline & Mean \pm Std. & & & & & & & & & & 38.2 \\
\hline \multirow[t]{2}{*}{ S11 } & & & & & & & & & & & \\
\hline & Mean \pm Std. & 26.8 & & $0.88 \pm 0.15$ & $0.06 \pm 0.05$ & 0.26 & $0.12 \pm$ & & $7.27 \pm$ & 243.86 & \\
\hline \multicolumn{12}{|l|}{ seasons } \\
\hline \multirow[t]{2}{*}{ Winter } & & & & & & & & & & & \\
\hline & & & & & & & & & & & \\
\hline \multirow[t]{2}{*}{ Spring } & & & & & & & & & & 64.7 & 14.7 \\
\hline & Mean \pm Std. & & & & & & & & & & $32.50 \pm 11$ \\
\hline \multirow[t]{2}{*}{ Summer } & & & & & & & & & & & \\
\hline & Mean \pm Std. & $27.52 \pm 2.18$ & $34.40 \pm 0.18$ & $1.04 \pm 0.23$ & $0.06 \pm 0.05$ & & $0.11 \pm 0.12$ & 10.4 & $7.20 \pm 2$ & $156.86 \pm 96.63$ & $24.48 \pm 15.5$ \\
\hline \multirow[t]{2}{*}{ Autumn } & & & & & & & & & & & \\
\hline & & & & & & & & & & & \\
\hline
\end{tabular}

TABLE 4. - Pearson correlation coefficients among the environmental variables and phytoplankton in Sanya Bay in four seasons $2005(* P<0.05$,

\begin{tabular}{|c|c|c|c|c|c|c|c|c|c|c|c|}
\hline Seasons & algae group & temperature & salinity & $\mathrm{PO}_{4}-\mathrm{P}$ & $\mathrm{SiO}_{3}-\mathrm{Si}$ & $\mathrm{NO}_{3}-\mathrm{N}$ & $\mathrm{NO}_{2}-\mathrm{N}$ & $\mathrm{NH}_{4}-\mathrm{N}$ & $\mathrm{Si} / \mathrm{N}$ & $\mathrm{Si} / \mathrm{P}$ & $\mathrm{N} / \mathrm{P}$ \\
\hline \multirow[t]{5}{*}{ Winter } & green algae & $-0.916 * *$ & -0.051 & 0.397 & 0.092 & $0.628 * *$ & $0.531 *$ & $0.652 * *$ & $-0.498 *$ & -0.1 & 0.066 \\
\hline & cyanobacteria & $0.694 * *$ & -0.152 & -0.217 & 0.124 & -0.373 & -0.319 & $-0.43 *$ & $0.435^{*}$ & 0.103 & -0.02 \\
\hline & diatoms and & $-0.85^{* *}$ & -0.16 & $0.513^{* *}$ & 0.262 & $0.747 * *$ & $0.667 * *$ & $0.755^{* *}$ & $-0.438 *$ & -0.126 & 0.041 \\
\hline & $\begin{array}{l}\text { dinoflagellates } \\
\text { cryptophyta }\end{array}$ & $0.773 * *$ & -0.07 & -0.253 & -0.131 & -0.391 & -0.343 & -0.405 & 0.302 & 0.016 & -0.087 \\
\hline & total conc. & $-0.867 * *$ & -0.163 & $0.509 * *$ & 0.252 & $0.748 * *$ & $0.662 * *$ & $0.755^{* *}$ & $-0.45^{*}$ & -0.123 & 0.046 \\
\hline \multirow[t]{5}{*}{ Spring } & green algae & -0.007 & $-0.843 * *$ & 0.326 & $0.511^{*}$ & $0.924 * *$ & $0.607 * *$ & $0.774 * *$ & $-0.433^{*}$ & -0.015 & $0.769 * *$ \\
\hline & cyanobac & & & & & -0.156 & & -0.077 & 0.084 & 0.018 & -0.178 \\
\hline & diatoms and & 0.08 & $-0.85 * *$ & $0.457 *$ & $0.565 * *$ & $0.934 * *$ & $0.591 * *$ & $0.835 * *$ & -0.416 & -0.043 & $0.707 *$ \\
\hline & cryptophy & 0.088 & 0.228 & -0.129 & -0.009 & -0.162 & 0.113 & -0.263 & 0.212 & 0.13 & -0.141 \\
\hline & total conc. & 0.074 & $-0.852 * *$ & $0.446^{*}$ & $0.564 * *$ & $0.938^{* *}$ & $0.601 * *$ & $0.832 * *$ & -0.419 & -0.039 & $0.717 * *$ \\
\hline \multirow[t]{5}{*}{ Summer } & green algae & $-0.727 * *$ & 0.36 & 0.136 & 0.274 & 0.327 & 0.341 & -0.045 & 0.113 & 0.196 & 0.026 \\
\hline & cyanobacteria & 0.244 & -0.365 & -0.131 & -0.019 & -0.069 & & -0.3 & 0.215 & -0.028 & 0.020 \\
\hline & diatoms and & $-0.976 * *$ & $0.62 * *$ & 0.31 & 0.301 & 0.341 & 0.257 & 0.03 & 0.07 & 0.159 & 0.002 \\
\hline & cryptophyta & 0.308 & -0.356 & -0.214 & -0.033 & -0.121 & -0.097 & -0.312 & 0.174 & 0.04 & 0.06 \\
\hline & total chlorophyll $a$ & $-0.965 * *$ & $0.598 * *$ & 0.294 & 0.305 & 0.346 & 0.273 & 0.017 & 0.079 & 0.168 & 0.005 \\
\hline \multirow[t]{5}{*}{ Autumn } & green algae & 0.149 & 0.163 & $0.434 *$ & 0.352 & $0.458^{*}$ & $0.535^{*}$ & $0.447 *$ & $0.519 *$ & 0.391 & 0.212 \\
\hline & cyanobacteria & $0.603 * *$ & 0.12 & $0.593 * *$ & $0.632 * *$ & $0.596 * *$ & $0.547 * *$ & $0.579 * *$ & & 0.132 & 0.131 \\
\hline & $\begin{array}{l}\text { diatoms and } \\
\text { dinoflagellates }\end{array}$ & 0.356 & 0.13 & 0.134 & 0.086 & 0.137 & 0.223 & 0.148 & 0.308 & 0.273 & 0.053 \\
\hline & nyta & $0.753 * *$ & 0.059 & 0.066 & 0.116 & 0.085 & 0.166 & 0.059 & 0.127 & 0.056 & 0.211 \\
\hline & total conc. & 0.242 & 0.174 & 0.391 & 0.343 & 0.394 & $0.453^{*}$ & 0.403 & 0.369 & 0.368 & 0.018 \\
\hline
\end{tabular}

Seasonal variation of dissolved inorganic nitrogen showed that the highest value was detected in autumn, and the lowest value occurred in winter in the Bay $(\mathrm{Ta}-$ ble 3). Correlation analysis showed that green algae, diatoms and dinoflagellates, and total chlorophyll $a$ concentration had highly significant correlations with 
dissolved inorganic nitrogen in winter and spring. In autumn, cyanobacteria showed significant positive correlation with dissolved inorganic nitrogen. In summer dissolved inorganic nitrogen was not the limiting factor on phytoplankton in the Bay (Table 3 and 4).

The mean value of phosphate $\left(\mathrm{PO}_{4}-\mathrm{P}\right)$ concentration ranged between 0.08 to $0.40 \mu \mathrm{mol} \mathrm{L}^{-1}$, the highest average concentration occurred at station S01, the lowest value were detected at station S09. In winter, the Bay had the highest average phosphate and the lowest value in spring. In winter and spring, phosphate was the limiting factor on diatoms and dinoflagellates, and total chlorophyll $a$ concentration. In autumn, phosphate was the limiting factor on green algae and cyanobacteria groups (Table 3 and 4).

The average concentration of silicate $\left(\mathrm{SiO}_{3}-\mathrm{Si}\right)$ ranged from 10.09 to $26.355 \mu \mathrm{mol} \mathrm{L}-1$. The highest mean value of silicate was detected at S1. The lowest average silicate was detected in S08. The highest mean value of silicate was detected in autumn, and the lowest value occurred in spring. In spring, silicate showed significantly positive correlation with diatoms and dinoflagellates, and total chlorophyll $a$ concentration (Table 3 and 4).

The nutrient molar ratios ranges of $\mathrm{Si} / \mathrm{N}, \mathrm{Si} / \mathrm{P}$, and N/P were 3.34-7.27, 101.31-246.61, and 31.96-52.90, respectively. The lowest average $\mathrm{Si} / \mathrm{N}$ was detected in spring and the highest in winter. Both lowest average $\mathrm{Si} / \mathrm{P}$ and N/P were detected in winter, and the highest value of both occurred in autumn. The ratio of $\mathrm{Si} / \mathrm{N}$ showed negative correlation with green algae, diatoms and dinoflagellates, and total chlorophyll $a$ in winter. The ratio of N/P showed significantly positive correlation with green algae, diatoms and dinoflagellates, and total chlorophyll $a$ in spring (Table 3 and 4).

\section{DISCUSSION}

The total chlorophyll $a$ concentration in Sanya Bay is generally lower than that of Daya Bay and Zhujiang Estuary (Huang et al., 2003; Tan et al., 2004; Li et al., 2006; Wang et al., 2006). The annual chlorophyll $a$ concentration was higher than that obtained during previous investigation (Huang et al., 2003). Diatoms and dinoflagellates group was the dominant phytoplankton in the Bay all year. Phytoplankton assemblage of Sanya Bay was often found dominated by the diatoms in terms of genus number and density compared to the other taxonomic groups, which agrees with the results of Huang et al. (2003) and Yang et al. (2007) who also reported the higher abundance of diatoms in seawater compared to other phytoplankton groups. The results from Pearl River estuary and Sepanggar Bay (Malaysia) also reported that most phytoplankton genera belong to diatoms (Huang et al., 2004; Sidik et al., 2008).

Variations of phytoplankton have been linked to light, macronutrient availability, temperature, salinity and zooplankton grazing in tropical and subtropical water systems (Fu and Bell, 2003a, b; Chen et al.,
2004; Chen, 2005; Ramirez et al., 2005; Cynthia and Jorge, 2006; Li et al., 2006). Sanya Bay is a tropical bay, the temperature of sea water was higher than $20^{\circ} \mathrm{C}$ all year round. So temperature was not the controlling factor of total phytoplankton chlorophyll $a$ concentration. The inshore stations showed lower water temperature and higher nutrient content in winter, and lower salinity and higher nutrient content in spring, and the phytoplankton chlorophyll $a$ concentration of inshore stations was higher than outer Bay water area in these two seasons. This suggested that compared to water temperature and salinity, dissolved organic nutrient was the main regulating factor for phytoplankton distribution in these two seasons.

The vertical and seasonal variations and distributions of water temperature suggest that thermocline occurred during May-August. In May the thermocline was caused by solar irradiation and during June-August by an exotic cold-water upwelling (Dong et al., 2002; Huang et al., 2003). The thermocline disappeared from September to the following March, and the seawater mixed. The thermocline in Sanya Bay reveals that there was no obvious vertical distribution and stratification in the area of inshore stations. The results from Shang et al. (2004) suggested that the difference in upwelling patterns were determined by the wind intensity and direction. In Sanya Bay the costal-upwelling forced by southwest monsoon and the strong stratification events occurred at stations which located in the outer and south area of the Bay. Great changes took place on phytoplankton vertical distribution during the stratification events. Total phytoplankton chlorophyll $a$ concentration in bottom layer increased sharply and much more than surface layer. Cyanobacteria and cryptophyta decreased and almost disappeared, however, the concentration of green algae and diatoms and dinoflagellates groups increased. In bottom layer, the concentration of diatoms and dinoflagellates group increased sharply, which was about eight times more than that in the surface layer. This stable stratification is caused by Wind-driven costal upwelling. Winddriven costal upwelling is an important phenomenon that leads to the water temperature drop (Landry et al., 1998; Shang et al., 2004; Varela et al., 2005) and phosphorus enrichment and low DIN/DIP ratios in the euphotic layer (Niemi, 1973; Haapala, 1994; Alenius et al., 1998). The transport of phosphorus potentially promotes growth of the phytoplankton. In addition, a lot of pelagic species such as Thalassiosira subtilis entered into the day during the stratification events. This suggested that cold-water upwelling was the leading factor influencing on phytoplankton distribution in the bay in summer.

Based on the low DIN/DIP ratio in the water in stratification events, the nitrogen-fixing cyanobacteria would be expected to benefit from the phosphorus enrichment of the surface layer with a delay in the biomass response because of the growth inhibition by the low temperatures (Lehtimaki et al., 1997; Vahtera et 
al., 2005). In autumn when the temperature increased the concentration of cyanobacteria increased greatly. Previous results suggested that monsoons may play a significant role in the distribution of predominant cyanobacteria Trichodesmium in Sanya Bay, and in autumn Trichodesmium abundance increased during the period of the transition from the SW to the NE monsoon (Dong et al., 2008).

In conclusion, dissolved inorganic nutrient especially phosphate and inorganic nitrogen and coldwater upwelling were the main regulating factor for phytoplankton distribution, which was consistent with the previous results conducted by cell counts method (Yang et al., 2007).

\section{ACKNOWLEDGEMENTS}

The research was supported by National Nature Science Fund (Grant: No. 41006069, No. 40776069), the Hainan Natural Science Fond (No. 809059), Key Projects in the National Science and Technology Pillar Program (No. 2009BAB44B03), the Knowledge Innovation Program of Chinese Academy of Sciences (Grant: No. KSCX2-SW-132), the Sanya Station Database and the Information System of CERN, the Field Station Fund of CAS.

\section{REFERENCES}

Alenius, P., K. Myrberg and A. Nekrasov. - 1998. The physical oceanography of the Gulf of Finland: a review. Boreal Environ. Res., 3: 97-125.

Arnaud, C., T. Marc and B. Cecile. - 2008. Design and application of a stratified sampling strategy to study the regional distribution of cyanobacteria (Ile-de-France, France). Water Res., 42: 4989-5001.

Beutler, M., K.H. Wiltshire, B. Meyer, C. Moldaenke, C. Luring, M. Meyerhofer, U.P. Hansen and H. Dau. - 2002. A fluorometric method for the differentiation of algal populations in vivo and in situ. Photosynth. Res., 72(1): 39-53.

Blanco, A.C., K. Nadaoka and T. Yamamoto. - 2008. Planktonic and benthic microalgal community composition as indicators of terrestrial influence on a fringing reef in Ishigaki Island, Southwest Japan. Mar. Environ. Res., 66: 520-535.

Chen, Y.L.L. - 2005. Spatial and seasonal variations of nitratebased new production and primary production in the South China Sea. Deep-Sea Res. Part I, 52: 319-340.

Chen, Y.L.L., H.Y. Chen, D.M, Karl and M. Takahashi. - 2004. Nitrogen modulates phytoplankton growth in spring in the South China Sea. Cont. Shelf Res., 24: 527-541.

Cynthia, A.G. and A.H.S. Jorge. - 2006. Variations of phytoplankton community structure related to water quality trends in a tropical karstic coastal zone. Mar. Pollut. Bull., 52(1): 48-60

Desiderio, R.A., C. Moore, C. Lantz and T.J. Cowles. - 1997. Multiple excitation fluorometer for in situ oceanographic applications. Applied Optics, 36: 1289-1296.

Dong, J.D., H.K. Wang, S. Zhang and L.M. Huang. - 2002. Vertical distribution characteristics of seawater temperature and DIN in SanYa Bay. J. Trop. Oceanogr., 21(1): 40-47.

Dong, J.D., Y.Y. Zhang, Y.S. Wang, S. Zhang and H.K. Wang. - 2008. Spatial and seasonal variations of Cyanobacteria and their nitrogen fixation rates in Sanya Bay, South China Sea. Sci. Mar., 72(2): 239-251

Fu, F.X. and P.R.F. Bell. - 2003a. Effect of salinity on growth, pigmentation, $\mathrm{N}_{2}$ fixation and alkaline phosphatase activity of cultured Trichodesmium sp. Mar. Ecol. Prog. Ser., 257: 69-76.

Fu, F.X. and P.R.F. Bell. - 2003b. Factors affection N 2 Fixation by the cyanobacterium Trichodesmium sp. GBRTRLI101. FEMS
Microb. Ecol., 45: 203-209.

Gregor, J. B. Marsalek. - 2004. Freshwater phytoplankton quantification by chlorophyll $a$ : a comparative study of in vitro, in vivo and in situ methods. Water Res., 38: 517-522.

Gregor, J., R. Geris, B. Marsalek, J. Hetesa and P. Marvan. - 2005. In situ quantification of phytoplankton in reservoirs using a submersible spectrofluorometer. Hydrobiologia, 548: 141-151.

Gregor, J., B. Marsalek and H. Sipkova. - 2007. Detection and estimation of potentially toxic cyanobacteria in raw water at the drinking water treatment plant by in vivo fluorescence method. Water Res., 41: 228-234.

Haapala, J. - 1994. Upwelling and its influence on nutrient concentration in the coastal area of the Hanko Peninsula, entrance of the Gulf of Finland. Estuar. Coast. Shelf Sci., 38: 507-521.

Huang, L.M., Y.H. Tan, X.Y. Song, X.P. Huang, H.K. Wang, S. Zhang, J.D. Dong and R.Y. Chen. - 2003. The status of the ecological environment and a proposed protection strategy in Sanya Bay, Hainan Island, China. Mar. Pollut. Bull., 47: 180-186.

Huang L.M., W.J. Jian, X.Y. Song, X.P. Huang, S. Liu, P.Y. Qian, K.D. Yin and M. Wu. - 2004. Species diversity and distribution for phytoplankton of the Pearl River estuary during rainy and dry seasons. Mar. Pollut. Bull., 49: 588-596.

Izydorczyk, K., C. Carpentier, J. Mrowczynski, A. Wagenvoort, T. Jurczak and M. Tarczynska. - 2009. Establishment of an alert level framework for cyanobacteria in drinking water resources by using the Algae Online Analyser for monitoring cyanobacterial chlorophyll a. Water Res., 43: 989-996.

Landry, M.R., S.L. Brown, L. Campbell, J. Constantinou and H. Liu. - 1998. Spatial patterns in phytoplankton growth and microzooplankton grazing in the Arabian Sea during monsoon forcing. Deep-Sea Res. Part II, 45: 2353-2368.

Lehtimaki, J., P. Moisander, K. Sivonen and K. Kononen. - 1997. Growth, nitrogen fixation, and nodularin production by two Baltic Sea cyanobacteria. Appl. Environ. Microb., 63(5): $1647-1656$

Li, K.Z., J.Q. Yin, L.M. Huang and Y.H. Tan. - 2006. Spatial and temporal variations of mesozooplankton in the Pearl River estuary, China. Estuar. Coast. Shelf Sci., 67(4): 543-552.

Niemi, A. - 1973. Ecology of phytoplankton in the Tvarminne area, SW coast of Finland. 1. Dynamics of hydrography, nutrients, chlorophyll $a$ and phytoplankton. Acta Bot. Fenn., 100: 1-68.

Ramirez, T., D. Cortes, J.M. Mercado, M.V. Yanez, M. Sebastian and E. Liger. - 2005. Seasonal dynamics of inorganic nutrients and phytoplankton biomass in the NW Alboran Sea. Estuar. Coast. Shelf Sci., 65(4): 654-670.

Shang, S.L., C.Y. Zhang, H.S. Hong, S.P. Shang and F. Chai. - 2004. Short-term variability of chlorophyll associated with upwelling events in the Taiwan Strait during the southwest monsoon of 1998. Deep-Sea Res. Part II, 51(10-11): 1113-1127.

SidiK, M.J., M. Rashed-Un-Nabi and M. Hoque. - 2008. Distribution of phytoplankton community in relation to environmental parameters in cage culture area of Sepanggar Bay, Sabah, Malaysia. Estuar. Coast. Shelf Sci., 80(2): 251-260.

Tan, Y.H., L.M. Huang, Q.C. Chen and X.P. Huang. - 2004. Seasonal variation in zooplankton composition and grazing impact on phytoplankton standing stock in the Pearl River Estuary, China. Cont. Shelf Res., 24: 1949-1968.

Serra, T., J. Vidal, X. Casamitjana, M. Soler and J. Colomer. - 2007. The role of surface vertical mixing in phytoplankton distribution in a stratified reservoir. Limnol. Oceanogr., 52(2): 620-634.

Vahtera, E., J. Laanemets, J. Pavelson, M. Huttunen and K. Kononen. - 2005. Effect of upwelling on the pelagic environment and bloom-forming cyanobacteria in the western Gulf of Finland, Baltic Sea. J. Mar. Syst., 58: 67-82.

Varela, M., R. Prego, Y. Pazos and A. Morono. - 2005. Influence of upwelling and river runoff interaction on phytoplankton assemblages in a Middle Galician Ria and Comparison with northern and southern rias (NW Iberian Peninsula). Estuar. Coast. Shelf Sci., 64: 721-737.

Wang, Y.S., Z.P. Lou, C.C. Sun and S.H. Han. - 2006. Multivariate statistical analysis of water quality and phytoplankton characteristics in Daya Bay, China, from 1999 to 2002. Oceanology, 48(2): 193-211.

Wilkinson, C. - 2000. Status of coral reefs of the world: 2000. Global Coral Reef Monitoring Network, Australian Institute of Marine Science, Cape Ferguson, Queenslang.

Yang, Z.H., J.D. Dong, M.L. Wu, Y.Y. Zhang, H.K. Wang, S. 
Zhang, Y.S. Wang, C.C. Sun and W.H. Zhou. - 2007. Structure characteristics of phytoplankton community at Sanya Bay. J. Trop. Oceanogr., 26(6): 62-66.

Zhang, Q.M. - 2001. On biogeomorphology of Luhuitou fringing reef of Sanya City, Hainan Island, China. Chin. Sci. Bull., 46: 97-102.

Ziegmann, M., M. Abert, M. Muller and F.H. Frimmel. - 2010. Use of fluorescence fingerprints for the estimation of bloom formation and toxin production of Microcystis aeruginosa. Water Res., 44: 195-204.
Znachor1, P., E. Zapomelov, K. Rehkov, J. Nedoma and K. Simek. -2008 . The effect of extreme rainfall on summer succession and vertical distribution of phytoplankton in a lacustrine part of a eutrophic reservoir. Aquat. Sci., 70: 77-86.

Scient. ed.: D. Vaqué.

Received November 2, 2009. Accepted April 7, 2010.

Published online September 23, 2010. 